\title{
A new species of Podanotum Torres \& Johnson, 1996 (Lepidoptera, Lycaenidae) from northern Peru
}

\author{
Una nueva especie de Podanotum Torres \& Johnson, 1996 (Lepidoptera, Lycaenidae) en \\ el norte de Perú
}

\section{Jackie Farfán ${ }^{1}$}

https://orcid.org/0000-0001-5913-0756

jjackie4u@gmail.com

José Cerdeña* 1

https://orcid.org/0000-0003-3930-6480 cerdenajoseal@yahoo.es

Ana Lazo-Rivera ${ }^{2}$

https://orcid.org/0000-0002-6925-6149

alazor@unsa.edu.pe

Wilson Huanca-Mamani ${ }^{3}$

https://orcid.org/0000-0003-2321-7416

whuanca@yahoo.com

\section{Zsolt Bálint ${ }^{4}$}

https://orcid.org/0000-0001-8174-878X

balint.zsolt@nhmus.hu

\section{*Corresponding author}

1 Universidad Nacional de San Agustín de Arequipa, Museo de Historia Natural, Av Alcides Carrión s/n, Arequipa, Peru.

2 Universidad Nacional de San Agustín de Arequipa, Escuela Profesional de Biología, Av Alcides Carrión $\mathrm{s} / \mathrm{n}$, Arequipa, Peru.

3 Departamento de Producción Agrícola, Facultad de Ciencias Agronómicas, Universidad de Tarapacá, Arica, Chile.

4 Hungarian Natural History Museum, Department of Zoology, H-1088 Budapest, Baross utca 13, Hungary.

\section{Citación}

Farfán J, Cerdeña J, Lazo-Rivera A, Huanca-Mamani W, Bálint Z. 2021. A new species of Podanotum Torres \& Johnson, 1996 (Lepidoptera, Lycaenidae) from northern Peru. Revista peruana de biología 28(4): e20968 (Noviembre 2021). doi: https://dx.doi.org/10.15381/ rpb.v28i4.20968
Presentado:
$05 / 08 / 2020$
Aceptado:
$15 / 10 / 2021$
Publicado online: 26/11/2021

Editor:

Diana Silva

\section{Abstract}

We describe a new species of the genus Podanotum Torres \& Johnson, 1996, Podanotum pajaten Farfán, Cerdeña \& Bálint sp. nov. from northern Peru, associated with the Andean treeline ecotone adjacent to cloud forest and wet grassland at $3200 \mathrm{~m}$ above sea level. Description of this new species is based on one female adult and is distinguishable from its congeners by the combination of the following morphological characters: dorsal wing pale blue, forewing discoidal line present on ventral side, hindwing tailed, and ostium bursae distally toothed. Podanotum pajaten sp. nov. is separated geographically from the closest spatial species, P. glorissimum Bálint \& Wojtusiak, 2002, by approximately $100 \mathrm{~km}$ to the south, and represents the second species described for Peru. An identification key to all known species of Podanotum is provided, stating their distributions by country.

\section{Resumen}

Se describe una nueva especie del género Podanotum Torres \& Johnson, 1996, Podanotum pajaten Farfán, Cerdeña \& Bálint sp. nov. del norte de Perú, asociada al ecotono andino entre bosque nublado y pastizal húmedo a 3,200 metros de altitud. La descripción de esta nueva especie está basada en una hembra adulta que se distingue de sus congéneres por la combinación de los siguientes caracteres morfológicos: vista dorsal de las alas de color azul pálido, línea postdiscal del ala anterior presente en vista ventral, cola corta en ala posterior, y parte distal del ostium bursae dentada. Podanotum pajaten sp. nov. está separada geográficamente de la especie espacialmente más cercana, $P$. glorissimum Bálint \& Wojtusiak, 2002, por aproximadamente $100 \mathrm{~km}$ hacia el sur, y representa la segunda especie descrita de Perú. Una clave de identificación es presentada para todas las especies conocidas de Podanotum, con indicación de los países de ocurrencia.

Keywords:

Andes; cloud forest; Río Abiseo National Park; Eumaeini; new species.

Palabras clave:

Andes; bosque nublado; Parque Nacional Río Abiseo; Eumaeini; nueva especie.

Publicación registrada en Zoobank/ZooBank article registered

LSIDurn:Isid:zoobank.org:pub:FE6C35CF-2609-410C-9CB5-57737D02DFC3

Acto nomenclatural/nomenclatural act:

Podanotum pajaten Farfán, Cerdeña \& Bálint, 2021

LSIDurn:Isid:zoobank.org:act:B8CE9125-0182-4DAB-BD92-D15DC4E16C47 


\section{Introduction}

The Tropical Andes region is an important centre of South-American biodiversity (Hoorn et al. 2010), containing hotspots for plant and animal biodiversity (Myers et al. 2000, Young et al. 2002, Swenson et al. 2012). In this region, the transition zone between the upper montane forest and wet grasslands (the treeline ecotone) is of particular interest due to its outstanding species and functional diversity (Bader et al. 2007, Ramírez et al. 2009, Hofstede et al. 2014, Peters et al. 2014, Llambí 2015) with high endemism rates for many taxa of Lepidoptera (Willmott et al. 2001, Lamas 2003, Pyrcz 2004, Hall 2005, Ignatov et al. 2011, Pyrcz et al. 2014, Sublett et al. 2019), including Lycaenidae (e.g. Prieto \& Bálint 2007, Prieto \& Rodríguez 2012).

In 2016, during an entomological expedition carried out to the high mountains of the Tropical Andes of northern Peru, one female adult of an undetermined Eumaeine species was collected, and provisionally labelled as "Lycaenidae sp." in the scientific collection of the Museo de Historia Natural, Universidad Nacional de San Agustín de Arequipa (MUSA). Recently, we examined this specimen and consider that it belongs to the genus Podanotum Torres \& Johnson, 1996 (Lycaenidae: Eumaeini) due to its wing pattern and female genitalia characters. Podanotum currently contains eleven described species (Robbins 2004, Bálint \& Wojtusiak 2006, Bálint \& Attal 2007, Prieto \& Rodríguez 2012) distributed from Venezuela to southern Peru, along the upper montane forests of the Tropical Andes (Bálint \& Wojtusiak 2006, Lamas et al. 2021).

Torres et al. (1996) enumerated the morphological diagnostic characters of Podanotum, including a bipartite habitus with sclerotized terminal element in the female genitalia. Moreover, it was recorded that sexual dimorphism in the genus is limited, male and female phenotypes being very similar to each other (Bálint \& Wojtusiak 2006, Bálint \& Attal 2007, Prieto \& Rodríguez 2012). The single specimen recently collected in Peru represents a hitherto unknown phenotype. Therefore, the aim of this study is to describe formally a new species of Podanotum, based on one female specimen collected in northern Peru at $3200 \mathrm{~m}$ elevation and to place it amongst congeners with the help of a key to identification.

\section{Material and methods}

Material examined. One female specimen of Podanotum was examined from the Museo de Historia Natural, Universidad Nacional de San Agustín de Arequipa, Arequipa, Peru (MUSA). Photographs of all type specimens of Podanotum taxa were examined from images available in Bálint \& Wojtusiak (2002), Prieto \& Rodríguez (2012), and Warren et al. (2017).

Morphological analysis. The abdomen was removed from the specimen and soaked in a $10 \% \mathrm{KOH}$ solution for ten minutes. Subsequently, the abdomen was preliminarily cleaned out of soft tissue in water in order to expose the genitalia, afterwards stained with chlorazol black in order to identify the soft parts. Water was extracted from the dissected genitalia by using 90\% and 95\% ethanol solutions. Wing venation and genitalic terminology follows Nicolay (1977) and Klots (1970) respectively. Measurements are in millimetres and were made from photographs of specimen taken next to a scale and magnified on a computer screen. Photographs of adult were taken with a Nikon D610 digital camera through a Nikkor 105 $\mathrm{mm} \mathrm{f/2.8G} \mathrm{AF-S} \mathrm{VR} \mathrm{Micro} \mathrm{lens;} \mathrm{photographs} \mathrm{of} \mathrm{genitalia}$ were taken with a camera Nikon DS-Ri2 through a Nikon SMZ25 stereomicroscope. Images were assembled and edited in Nikon NIS-Elements and Photoshop CS5.1.

Genomic DNA was extracted from abdominal tissue, following the procedures described by Huanca-Mamani et al. (2015). A fragment of the COI gene was amplified by polymerase chain reaction (PCR) with the primers LEP-F1 and LEP R1 (Hebert et al. 2004). PCR reactions were performed in a final volume of $20 \mu \mathrm{L}$. Each reaction contained $1 \mu \mathrm{L}$ of DNA extract, 10 pmoles of each primer, $2.5 \mathrm{mM}$ of each dNTP, $2 \mathrm{mM} \mathrm{MgCl} 2,1 \mathrm{X}$ PCR buffer (KCl), 1 unit of Taq DNA polymerase (Thermo Scientific) and sterile distilled water. The amplification program was 5 min at $94{ }^{\circ} \mathrm{C}, 35$ cycles of $30 \mathrm{~s}$ at $94{ }^{\circ} \mathrm{C}, 30 \mathrm{~s}$ at $47^{\circ} \mathrm{C}, 1$ min at $72{ }^{\circ} \mathrm{C}$, and a final elongation step of $10 \mathrm{~min}$ at 72 ${ }^{\circ} \mathrm{C}$. Three $\mu \mathrm{L}$ of each PCR product was visualized on $1.5 \%$ agarose gel stained with gel-red (Biotium). Reactions containing fragments of the expected size were purified and directly sequenced by a commercial facility (Macrogen, South Korea).

The following abbreviations are used:

MUSM-Museo de Historia Natural, Universidad Nacional Mayor de San Marcos, Lima, Peru.

MUSA-Museo de Historia Natural, Universidad Nacional de San Agustín de Arequipa, Peru.

$$
\begin{aligned}
& \text { DFW-Dorsal forewing } \\
& \text { DHW-Dorsal hindwing } \\
& \text { VFW-Ventral forewing } \\
& \text { VHW-Ventral hindwing }
\end{aligned}
$$

Results

Podanotum pajaten Farfán, Cerdeña \& Bálint sp. nov.

Figs 1, 2

Type material. - Holotype, female: PERU, LL [La Libertad], Pataz, Parque Nacional Abiseo, Puerta del Monte, $3200 \mathrm{~m}, 0741 / 7727\left[7^{\circ} 41^{\prime} \mathrm{S}, 77^{\circ} 27^{\prime} \mathrm{W}\right], 19 . v .2016$, Leg. J. Farfán (MUSA) [will be deposited in MUSM]. Genbank accession number: OK484465.

Type locality. - Peru, La Libertad, Pataz, Puerta del Monte, $7^{\circ} 41^{\prime} \mathrm{S}, 77^{\circ} 27^{\prime} \mathrm{W}, 3200 \mathrm{~m}$.

Diagnosis. - Podanotum pajaten sp. nov. can be distinguished from the other known congeneric species by the following combination of characters: (1) dorsal wing surface pale blue colored (vs. brown color in $P$. andrew- 
neildi Bálint, 2001 and P. melanissimum Bálint \& Wojtusiak, 2006), (2) conspicuous discoidal line on the VFW (vs. absent in the other species except $P$. glorissimum, with metallic green dorsal wing surface and $P$. andrewneildi, with brown dorsal wing surface), (3) hindwing tailed (vs. absent in P. glorissimum), and (4) ostium bursae distally toothed (vs. untoothed in P. glorissimum).

\section{Description. -}

Female (Fig. 1). Forewing length $12.6 \mathrm{~mm}(\mathrm{n}=1)$.

Head: Primarily black with brown hairs dorsally, brown eyes with white hair-like scales around, hairy palpus with white hair-like scales, antenna striped white and black.

Thorax: Wings dorsally pale blue. DFW with broad blackish border (approx. $1.5 \mathrm{~mm}$ in width) to apical and outer margins. Hindwing rounded, DHW dark grayish brown border to outer margins with thin marginal black line, presence of slight tornal lobe and short brown tail.
Fringe on both wings formed of long light brown scales. Wings ventrally dark grayish brown. VFW with discal line, postmedian line terminates posteriorly at vein $\mathrm{Cu}_{2}$, and submarginal line terminates posteriorly at vein $\mathrm{A}_{2}$, all lines brown. VHW with discal line, postmedian line irregular terminates posteriorly at vein $\mathrm{Cu}_{2}$, and submarginal line with lunular spots (basally reddish brown, distally black scales) all lines reddish brown.

Abdomen: Blackish dorsally and light grey ventrally, with long white hairs.

Female genitalia (Fig. 2): Fluted lamella postvaginalis, ductus bursae distally sclerotized, prominent, toothed, anterior section of ductus bursae large and thin tube weakly sclerotized. Corpus bursae with two very large and shield-like signa, inwardly toothed in lateral view; anal papillae enlarged and elliptic with apophyses about half the size of the ductus bursae length, with the proximal tip bent.

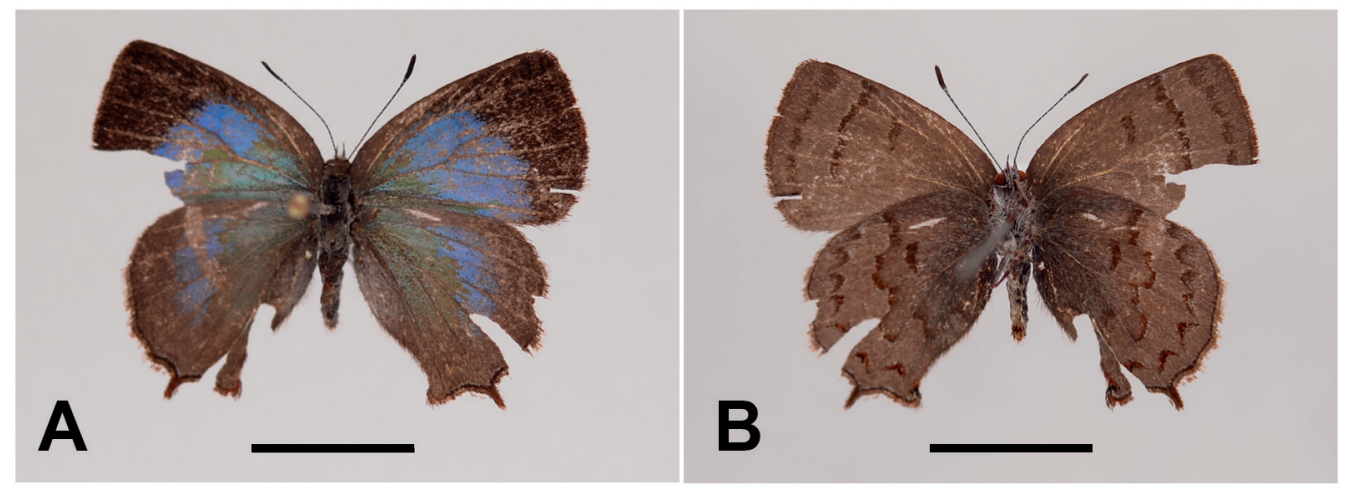

Figure 1. Adult female of Podanotum pajaten sp. nov., Holotype. A. dorsal view; B. ventral view. Scale bar: $10 \mathrm{~mm}$.

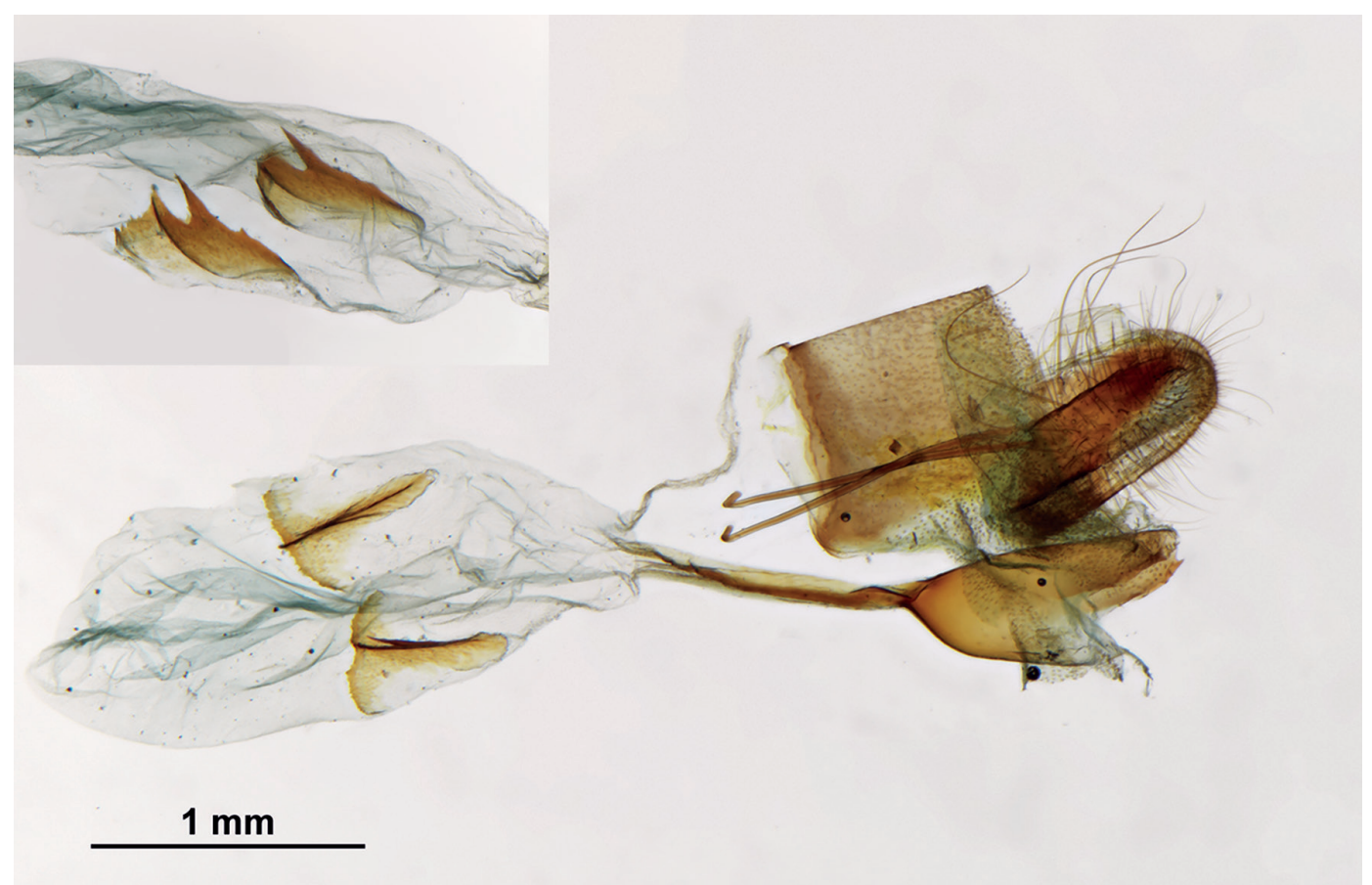

Figure 2. Podanotum pajaten sp. nov., female genitalia in lateral view; details of signa on upper left corner. Scale bar: $1 \mathrm{~mm}$. 


\section{Male: Unknown.}

Distribution: Podanotum pajaten is known only from the type locality in Río Abiseo National Park, at the treeline ecotone, approximately $100 \mathrm{~km}$ south of the type locality of the closest distributed species, P. glorissimum.

Etymology: The specific epithet is a masculine noun in apposition, derived from the "Gran Pajatén" archaeological site, which occurs in the Río Abiseo National Park, near where this new species was found.

\section{Host plant: Unknown.}

Remarks. - This new species is placed in the genus Podanotum (type species: Podanotum clarissimus Hall, Willmott \& Johnson, 1996, by original designation) by the following combination of diagnostic characters: dorsal wing blue green, VHW with submarginal band of blackish-brown lunules or chevrons, female genitalia with sclerotized terminal element (Torres et al. 1996), and VFW with postmedian line ending posteriorly at vein $\mathrm{Cu}_{2}$ (Robbins \& Busby 2015).

\section{Discussion}

According to Prieto \& Rodriguez (2012), the wing pattern of Podanotum is not geographically variable within species, so we discarded that this new species could be a variation or subspecies of another population of Podanotum previously described, and we are convinced that the species status of $P$. pajaten is fully justified; despite the description being based on a single somewhat damaged female specimen, it contains enough characters to differentiate it from other species of the genus, and considering that within the genus there is very little sexual dimorphism, it is probable that the males of $P$. pajaten are very similar to the female described herein.

In the Neotropical butterfly checklist (Robbins 2004) Podanotum was placed next to Penaincisalia Johnson, 1992 (type species: Thecla ? culminicola Staudinger, 1894, by original designation) in the Micandra Section of Eumaeini, based on genitalia and wing pattern. In a preliminary phylogenetic analysis with molecular data, Podanotum joined with Rhamma Johnson, 1992 (type species: Thecla oxida Hewitson, 1870) (Quental 2008).
Subsequently, Robbins \& Busby (2015) in a phylogenetic analysis with morphological evidence indicate that Podanotum is closely related to Lathecla Robbins, 2004 (type species: Thecla latagus Godman \& Savin, 1887). Therefore, further phylogenetic analysis, integrating morphological and molecular characters, is still required to determine the phylogenetic position of Podanotum.
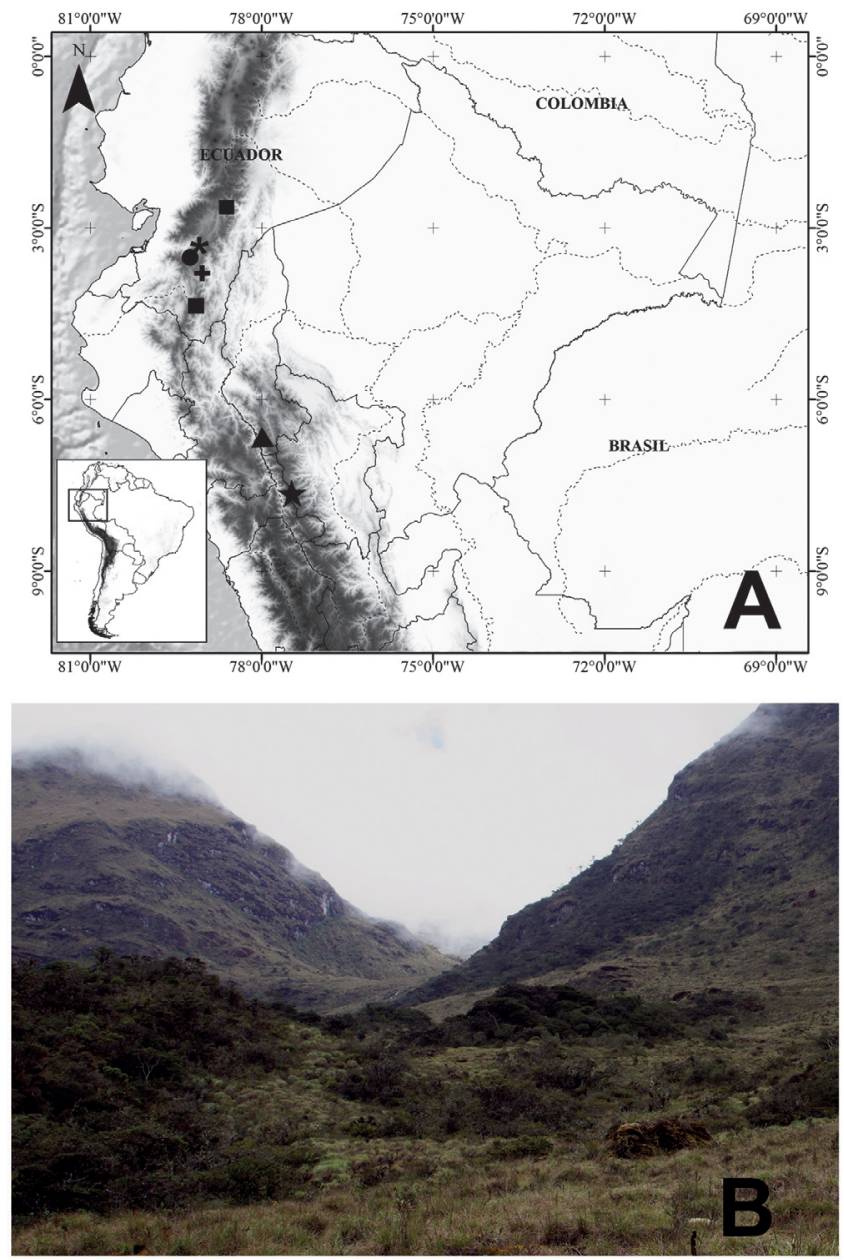

Figure 3. Distribution and habitat of Podanotum pajaten sp. nov. A. Distribution map of Podanotum species in Peru and Ecuador. $P$. pajaten sp. nov. $=$ star, $P$. glorissimum $=$ triangle, $P$. metallicus $=$ circle, $P$. melanissimum = asterisk, $P$. aquaphilum = square, $P$. magnificum $=$ cross; $\mathbf{B}$. Type locality of $P$. pajaten sp. nov.

\section{Key to Podanotum species with indications of country occurrence}

1_Hindwing $\mathrm{Cu}_{2}$ vein terminus with tail

2_Dorsal wing surface brown (Ecuador: Loja)

melanissimum Bálint \& Wojtusaik, 2006

_ Dorsal wing surface blue or green

3_Dorsal wing surface deep metallic green (Peru: Amazonas)

glorissimum Bálint \& Wojtusiak, 2002

_Dorsal wing surface light metallic green

4_Dorsal hind wing surface with wide ( $>2 \mathrm{~mm}$ ) black margin (Ecuador: Loja)

clarissimus Hall, Willmott \& Johnson, 1996

_Dorsal hindwing surface with narrow $(<1 \mathrm{~mm})$ or no black border

5_Ventral forewing postmedian line consists of scattered spots (Colombia: Antioquia)

pulsar Prieto \& Rodríguez, 2012.

_Vental forewing postmedian consists of continuous spots (Colombia: Boyacá) 
_Ventral forewing surface without discoidal line

8_Dorsal wing surface deeper blue, hindwing with narrow ( $>1 \mathrm{~mm})$ black border

9_Ventral forewing postmedian line slightly bent running to inner margin (Ecuador: Zamora-Chinchipe)

_Ventral forewing postmedian line straight running to tornus (Colombia: Cundinamarca) aquaphilum Bálint \& Attal, 2007

salaeides (Draudt, 1919)

10_Ventral forewing submedian and postmedian areas with identical color, postmedian line basally red (Colombia: Caldas) paramosa (Constantino \& Salazar, 1998)

_Ventral forewing postmedian area lighter than submedian, postmedian line basally brown

11_Ventral forewing submargin with white limbal pattern (Colombia: Cauca)

_Ventral forewing submargin with brown limbal pattern (Ecuador: Zamora-Chinchipe)

vanewrighti (Johnson \& Adams, 1993)

magnificum Bálint \& Attal, 2007

\section{Literature cited}

Bader MY, Rietkerk M, Bregt AK. 2007. Vegetation structure and temperature regimes of tropical alpine treelines. Arctic, Antarctic, and Alpine Research 39(3): 353-364. https://www.tandfonline.com/doi/ full/10.1657/1523-0430(06-055)[BADER]2.0.CO;2

Bálint Z, Attal S. 2007. Nouveaux Podanotum (Lepidoptera, Lycaenidae). Bulletin de la Société entomologique de France 112(4): 473-476.

Bálint Z, Wojtusiak J. 2006. Notes on the genus Podanotum with description of a new species (Lepidoptera: Lycaenidae: Eumaeini). Genus 17(2): 283-289.

Hall JPW. 2005. Montane speciation patterns in Ithomiola butterflies (Lepidoptera: Riodinidae): are they consistently moving up in the world?. Proceedings of the Royal Society of London B, Biological Sciences 272(1580): 2457-2466. https://doi.org/10.1098/ rspb.2005.3254.

Hebert, PDN, Penton EH, Burns JM, Janzen DH, Hallwachs W. 2004. Ten species in one: DNA barcoding reveals cryptic species in the neotropical skipper butterfly Astraptes fulgerator. Proceedings of the National Academy of Sciences 101(41): 14812-14817. http://dx.doi. org/10.1073/pnas.0406166101

Hofstede RGM, Dickinson KJM, Mark AF, Narváez E. 2014. A Broad Transition from Cloud Forest to Páramo Characterizes an Undisturbed Treeline in Parque Nacional Llanganates, Ecuador. Arctic, Antarctic, and Alpine Research 46(4): 975-986. https://doi. org/10.1657/1938-4246-46.4.975

Hoorn C, Wesselingh FP, ter Steege H, Bermúdez MA, Mora A, Sevink J, Sanmartín I, Sánchez-Meseguer A, Anderson CL, Figueiredo JP, Jaramillo C, Riff D, Negri FR, Hooghiemstra H, Lundberg J, Stadler T, Särkinen T, Antonelli A. 2010. Amazonia Through Time: Andean Uplift, Climate Change, Landscape Evolution, and Biodiversity. Science 330: 927-931. http://dx.doi. org/10.1126/science.1194585

Huanca-Mamani W, Rivera-Cabello D, Maita-Maita J. 2015. A simple, fast, and inexpensive CTAB-PVP-Silica based method for genomic DNA isolation from single, small insect larvae and pupae. Genetics and Molecular Research 14(3): 8001-8007. http://dx.doi. org/10.4238/2015.July.17.8
Ignatov II, Centeno P, Janovec JP, Tobler MW, Grados J, Lamas G. 2011. Patterns of richness, composition, and distribution of sphingid moths along an elevational gradient in the Andes-Amazon region of southeastern Peru. Annals of the Entomological Society of America 104(1): 68-76. https://doi.org/10.1603/AN09083

Klots AB. 1970. Lepidoptera, pp. 115-130. In: Tuxen SL (Ed) Taxonomist's Glossary of Genitalia in Insects. Munksgaard, Copenhagen, $359 \mathrm{pp}$.

Lamas G. 2003. Las Mariposas de Machu Picchu. Guía ilustrada de las mariposas del Santuario Histórico Machu Picchu, Cuzco, Perú. PROFONANPE, Lima. 221 pp.

Lamas G, McInnis ML, Busby RC, Robbins RK. 2021. The lycaenid butterfly fauna (Lepidoptera) of Cosñipata, Peru: annotated checklist, elevational patterns, and rarity. Insecta Mundi 0861: 1-34. https://journals.flvc.org/ mundi/article/view/128840/129958

Llambí LD. 2015. Estructura, diversidad y dinámica de la vegetación en el ecotono bosque-páramo: revisión de la evidencia en la Cordillera de Mérida. Acta Biologica Colombiana 20(3): 5-20. http://dx.doi.org/10.15446/ abc.v20n3.46721

Myers N, Mittermeier RA, Mittermeier CG, Da Fonseca GAB, Kent J. 2000. Biodiversity hotspots for conservation priorities. Nature 403: 853-858. http://dx.doi. org/10.1038/35002501

Nicolay SS. 1977. Studies in the genera of American hairstreaks. 4. A new genus of hairstreak from Central and South America (Lycaenidae: Eumaeini). Bulletin of the Allyn Museum 44: 1-24.

Peters T, Braeuning A, Muenchow J, Richter M. 2014. An ecological paradox: high species diversity and low position of the upper forest line in the Andean depression. Ecology and Evolution 4(11): 2134-2145. http://dx.doi. org/10.1002/ece3.1078

Prieto C, Bálint Z. 2007. Two new lycaenid butterfly species from the high Andes of Ecuador and Peru (Lep: Lycaenidae: Eumaeini). Folia Entomologica Hungarica 68: 157-171.

Prieto C, Rodríguez G. 2012. A new iridescent "elfin" butterfly species of Podanotum (Lepidoptera: Lycaenidae: Eumaeini) from the Colombian Andes. Zootaxa 3303: 59-64. http://dx.doi.org/10.11646/zootaxa.3303.1.4 
Pyrcz TW. 2004. Pronophiline butterflies of the highlands of Chachapoyas in northern Peru: faunal survey, diversity and distribution patterns (Lepidoptera, Nymphalidae, Satyrinae). Genus 15(4): 455-622.

Pyrcz TW, Willmott K, Garlacz R, Boyer P, Gareca Y. 2014. Latitudinal gradient and spatial covariance in species richness of tropical Lepidoptera in the Andes. Insect Conservation and Diversity 7(4): 355-364. https:// doi.org/10.1111/icad.12058

Quental TB. 2008. Systematics, sexual selection, and evolution of secondary sexual characters in Neotropical Eumaeini butterflies (Lepidoptera: Lycaenidae). PhD thesis, Cambridge, USA: Harvard University.

Ramírez L, Llambí LD, Schwarzkopf T, Gámez LE, Márquez NJ. 2009. Vegetation structure along the forest páramo transition belt in the Sierra Nevada de Mérida: implications for understanding the treeline dynamics. Ecotrópicos 22(2): 83-98.

Robbins RK. 2004. Checklist of Eumaeini. 98. Lycaenidae Theclinae, Eumaeini. 118-137 pp. In: Checklist of Neotropical Lepidoptera. Part 4A. Hesperioidea- Papilionoidea. G. Lamas (Ed). Atlas of Neotropical Lepidoptera. J. Heppner (series Ed.) Scientific publishers, Gainesville $439 \mathrm{pp}$.

Robbins RK, Busby RC. 2015. Evolutionary gain of male secondary sexual structures in the widespread Neotropical montane genus Lathecla (Lepidoptera, Lycaenidae, Eumaeini). Insect Systematics \& Evolution 46(1): 4778. http://dx.doi.org/10.1163/1876312X-45032115

Sublett CA, Cook JL, Janovec JP. 2019. Species richness and community composition of sphingid moths (Lepidoptera: Sphingidae) along an elevational gradient in southeast Peru. Zoologia (Curitiba) 36(e32938): 1-11. https:// doi.org/10.3897/zoologia.36.e32938

Swenson JJ, Young BE, Beck S, Comer P, Córdova JH, Dyson J, Embert D, Encarnación F, Ferreira W, Franke I, Grossman D, Hernandez P, Herzog SK, Josse C, Navarro G, Pacheco V, Stein BA, Timaná M, Tovar A, Tovar C, Vargas J, Zambrana-Torrelio CM. 2012. Plant and animal endemism in the eastern Andean slope: challenges to conservation. BMC Ecology 12(1): 1-18. http://dx.doi. org/10.1186/1472-6785-12-1

Torres-Núñez R, Hall JP, Willmott KR, Johnson K. 1996. A New Genus of "Elfin" Butterflies from the Northern High Andes (Lepidoptera: Lycaenidae). Tropical Lepidoptera 7(1)(1): 81-86.

Warren AD, Davis KJ, Stangeland EM, Pelham JP, Willmott KR, Grishin NV. 2017. Illustrated lists of American Butterflies. Available from: http://www.butterfliesofamerica.com (accessed 12 May 2021).

Willmott KR, Hall JPW, Lamas G. 2001. Systematics of Hypanartia (Lepidoptera: Nymphalidae: Nymphalinae), with a test for geographical speciation mechanisms in the Andes. Systematic Entomology 26(4): 369-399. https://doi.org/10.1046/j.1365-3113.2001.00157.x

Young KR, Ulloa CU, Luteyn JL, Knapp S. 2002. Plant evolution and endemism in Andean South America: an introduction. The Botanical Review 68(1): 4-21. https://doi.or g/10.1663/0006-8101(2002)068[0004:PEAEIA]2.0. $\mathrm{CO} ; 2$
Agradecimientos / Acknowledgments:

We are grateful to the staff of the Río Abiseo National Park for their support during the field trip expedition. Thanks to Dr. Evaristo López (Museo de Historia Natural, Universidad Nacional San Agustín, Arequipa, Perú [MUSA]) for access to the Animal Systematic Laboratory of Universidad Nacional San Agustin de Arequipa (UNSA)

Conflicto de intereses / Competing interests:

The authors declare no conflict of interest.

Rol de los autores / Authors Roles:

JF and JC: Conceptualization, Investigation, Writing - original draft, Writing-review \& editing. WHM: Investigation, Writing-original draft, Writing - review \& editing.

\section{Fuentes de financiamiento / Funding:}

This study has been supported in part by the project of the Universidad Nacional de San Agustin de Arequipa (UNSA) with Contract IBA-001-2019-UNSA.

\section{Aspectos éticos / legales; Ethics / legals:}

Authors declare that they did not violate or omit ethical or legal norms in this research. 